\title{
FORMULASI TEPUNG PISANG DAN TEPUNG MOCAF TERHADAP MUTU CAKE
}

\section{Formulation of Mocaf Flour and Banana Flour to Quality of Cake}

\author{
Syirril Ihromi1 ${ }^{*}$, Yeni Sulastri2 ${ }^{2}$ Fadlin Arisandi ${ }^{1}$ \\ 1Teknologi Hasil Pertanian, Universitas Muhammadiyah Mataram, syirrilihromi@ummat.ac.id \\ 2Ilmu dan Teknologi Pangan, Universitas Mataram
}

\section{INFO ARTIKEL}

\section{RiwayatArtikel:}

Diterima: 07- 03 - 2018

Disetujui : 11 - 07- 2018

\section{Kata Kunci:}

1 Formulasi

2 Tepung Pisang

3 Tepung Mocaf

4 Cake

\begin{abstract}
ABSTRAK
Abstrak: Pengembangan produk cake yang memanfaatkan tepung mocaf dan tepung pisang untuk menggantikan sebagian dan keseluruhan terigu ditujukan untuk memanfaatkan bahan pangan lokal, memperkaya nilai gizi cake dan juga untuk mengurangi ketergantungan pada tepung terigu. Penelitian ini bertujuan untuk mengetahui formulasi tepung mocaf dan tepung pisang yang tepat dalam pembuatan cake, dan mengetahui karakteristrik kimia dan organoleptik cake. Metode yang digunakan dalam penelitian ini adalah metode Eksperimental dengan menggunakan Rancangan Acak Lengkap (RAL) dengan percobaan faktor tunggal yaitu formulasi tepung mocaf dan tepung pisang, yang terdiri atas 5 taraf perlakuan, sebagai berikut P0 $=$ Formulasi Tepung mocaf $100 \%$ (Kontrol), P1 = Formulasi Tepung pisang $10 \%$ dan tepung mocaf 90\%, P2 = Formulasi Tepung pisang $20 \%$ dan tepung mocaf $80 \%$, P3 = Formulasi Tepung pisang 30\% dan tepung mocaf 70\%, P4 = Formulasi Tepung pisang $40 \%$ dan tepung mocaf $60 \%$, dan P5 $=$ Formulasi Tepung pisang $50 \%$ dan tepung mocaf 50\%. Masing- masing perlakuan diulang 3 kali sehingga di peroleh 18 unit percobaan. Data hasil pengamatan dianalisis dengan analisis keragaman (Analysis of variance) pada taraf nyata $5 \%$ dan diuji lanjut menggunakan uji Beda Nyata Jujur (BNJ) pada taraf nyata yang sama. Hasil penelitian menunjukkan bahwa formulasi tepung mocaf dan tepung pisang berpengaruh secara nyata terhadap kadar air, kadar abu, kadar pati, dan sifat organoleptik parameter rasa, warna, dan tekstur cake yang diamati. Semakin tinggi proporsi tepung pisang yang digunakan kadar air, kadar abu, dan kadar pati semakin meningkat. Semakin tinggi proporsi tepung pisang yang digunakan maka skor nilai rasa dan semakin meningkat dan disukai oleh panelis, sedangkan nilai tekstur cendrung semakin menurun. Perlakuan terbaik diperoleh pada perlakuan kelima (P5) dengan Formulasi Tepung pisang 50\% dan tepung mocaf $50 \%$.
\end{abstract}

Abstract: The development of cake products that use mocaf flour and banana flour to replace part and all of the flour is intended to utilize local food ingredients, enrich the nutritional value of the cake and also to reduce dependence on wheat flour. This study aims to determine the proper formulation of mocaf flour and banana flour in making cakes, and to know the chemical and organoleptic characteristics of the cake. The method used in this study is an experimental method using a Completely Randomized Design (CRD) with a single factor experiment namely the formulation of mocaf flour and banana flour, which consists of 5 levels of treatment, as follows P0 $=100 \%$ mocaf flour formulation (control), P1 $=$ Formulation of banana flour $10 \%$ and mocaf flour $90 \%$, P2 = Formulation of banana flour $20 \%$ and mocaf flour 80\%, P3 = Formulation of banana flour 30\% and mocaf flour 70\%, P4 $=$ Formulation of banana flour $40 \%$ and mocaf flour $60 \%$, and P5 = Formulation of $50 \%$ Banana Flour and 50\% mocaf flour. Each treatment was repeated 3 times so that we get 18 experimental units were obtained. Observation data were analyzed by analysis of variance at $5 \%$ significance level and further tested using the Honest Significant Difference (BNJ) test at the same level. The results showed that the formulation of mocaf flour and banana flour significantly affected the moisture content, ash content, starch content, and organoleptic properties of the observed taste, color, and texture parameters. The higher proportion of banana flour is used, the water content, ash content, and starch content are increasing. The higher the proportion of banana flour that is used, the higher value of flavor value and the preferred by panelists, while the texture value tends to decrease. The best treatment was obtained in the fifth treatment (P5) with 50\% Banana Flour Formulation and 50\% mocaf flour. 


\section{A. LATAR BELAKANG}

Cake atau bolu adalah makanan yang sangat populer saat ini. Rasanya yang manis dan bentuknya yang beragam menjadikan cake banyak digemari oleh masyarakat. Cake dapat disajikan sebagai makanan pembuka dan hidangan penutup. Saat ini cake juga dibuat dengan menggunakan bahan baku selain terigu.Variasi lain cake dapat dihias dengan lapisan (icing) dari krim mentega (buttercream), fondant, atau marzipan (Faridah dkk.,2008).

Cake adalah kue berbahan dasar tepung (umumnya tepung terigu), gula, dan telur. Cake umumnya dimatangkan dengan cara dipanggang di dalam oven. Cake adalah salah satu jenis makanan yang memiliki tekstur ringan, lembut disertai poripori yang relatif besar. Karakteristik ini antara lain dibentuk dari penggunaan putih telur yang di kocok kaku dan penggunaan jenis lemak dalam bentuk minyak serta perlakuan khusus lainnya.

Cake memiliki kandungan gizi yang cukup lengkap yaitu karbohidrat sebesar 57,1 g; protein 7,1 g; lemak $19,8 \mathrm{mg}$; kalsium $15 \mathrm{mg}$; fosfor $160 \mathrm{mg}$; besi $0,8 \mathrm{mg}$; vitamin A 65 IU; vitamin B1 0,06 mg; vitamin C $1 \mathrm{mg}$; dan energi sebanyak 435 kalori, dalam $100 \mathrm{~g}$ bahan (Kementrian Kesehatan Republik Indonesia 2010).

Cake yang berbahan dasar tepung terigu ini sangat digemari oleh masyarakat, produk cake semakin meningkat namun yang menjadi kelemahan dalam pengembangan produk cake yaitu bahan baku yang di gunakan dalam pembuatan cake yaitu tepung terigu. Tepung terigu dalam negeri di penuhi melalui impor sehingga biaya impor cukup besar. Untuk mengurangi volume impor maka perlu alternatif penggunaan tepung yang lain dalam pengembangan produk cake salah satunya tepung mocaf dan tepung pisang.

Pengembangan produk cake yang memanfaatkan tepung mocaf dan tepung pisang untuk menggantikan sebagian dan keseluruhan terigu ditujukan untuk memanfaatkan bahan pangan lokal, memperkaya nilai gizi cake dan juga untuk mengurangi ketergantungan pada tepung terigu. Pengembangan produk cake dilakukan dengan cara memformulasikan tepung pisang dan tepung mocaf pada jumlah tertentu, sehingga diperoleh formulasi yang tepat dengan hasil yang memenuhi kriteria cake.

Tepung mocaf diperoleh dari ubi kayu yang diproses melalui prinsip memodifikasi sel ubi kayu secara fermentasi (Raysita dan Pangesthi, 2012). Mocaf memiliki kandungan gizi meliputi kadar lemak $0,4 \%$, kadar serat 3,4\%, kadar pati 87,3\%, kadar abu $04 \%$, kadar protein 1,2\%, kadar air 6,9\% (Sutardi 2010). Tepung mocaf dapat digunakan sebagai pengganti tepung terigu atau campuran tepung terigu dan juga campuran tepung lainnya untuk pembuatan berbagai jenis kue salah satunya dalam pembuatan cake (Mocaf Indonesia, 2016).

Tepung pisang juga berpotensi sebagai bahan baku pembuatan cake yang dianjurkan, karena lebih tahan disimpan, mudah dicampur (dibuat komposit), diperkaya zat gizi (difortifikasi), dibentuk, dan lebih cepat dimasak sesuai tuntutan kehidupan modern yang serba praktis. Tepung pisang, tepung yang diperoleh dari danging buah pisang yang melalui proses pengeringan dan penggilingan. Tepung pisang mempunyai berbagai manfaat, biasanya dimanfaatkan sebagai campuran pada industri roti, dan salah satunya yaitu dalam pembuatan cake (Winarno, 2000). Tepung pisang memilki komposisi kimia yaitu karbohidrat $82,81 \%$, protein $4,84 \%$, karbohidrat $82,81 \%$, kadar air $9,08 \%$, kadar abu 2,93\%, dan lemak 1,07\% (Suyatni dan Supriadi A., 2008). Berdasarkan latar belakang diatas maka Penelitian ini bertujuan untuk mengetahui proporsi campuran tepung mocaf dan tepung pisang yang tepat dalam pembuatan cake dan mengetahui karakteristrik kimia dan organoleptik cake yang dihasilkan.

\section{B. METODE PENELITIAN \\ 1. Rancangan Penelitian}

Data dalam penelitian ini merupakan data primer yang langsung diperoleh dari hasil penentuan kadar air, kadar abu, kadar pati dan uji organoleptik. Data penelitian dianalisis menggunakan rancangan percobaan yaitu RAL (Rancangan Acak Lengkap)(Hanafiah, 1994). Perlakuan formulasi tepung pisang dengan tepung mocaf dilakukan dalam 6 aras perlakuan dengan 3 kali ulangan. Pendenahan dalam rancangan penelitian ini dapat dilihat pada Tabel 1.

Tabel 1. Pendenahan dalam rancangan percobaan

\begin{tabular}{ccccccc}
\hline & \multicolumn{5}{c}{ Taraf Perlakuan Formulasi Tepung Pisang } \\
dengan Tepung Mocaf (\%) \\
\cline { 2 - 6 } gan & $\mathbf{0 : 1 0 0}$ & $\mathbf{1 0 : 9 0}$ & $\mathbf{2 0 : 8 0}$ & $\mathbf{3 0 : 7 0}$ & $\mathbf{4 0 : 6 0}$ & $\mathbf{5 0 : 5 0}$ \\
\hline 1 & P0U1 & P1U1 & P2U1 & P3U1 & P4U1 & P5U1 \\
2 & P0U2 & P1U2 & P2U2 & P3U2 & P4U2 & P5U2 \\
3 & P0U3 & P1U3 & P2U3 & P3U3 & P4U3 & P5U3 \\
\hline
\end{tabular}

Keterangan :

$\mathrm{P}=$ Formulasi Tepung Pisang dengan Tepung Mocaf

$\mathrm{U}=$ ulangan $\mathrm{ke} 1,2,3$

Masing-masing perlakuan dilakukan ulangan sebanyak 3 kali ulangan sehingga diperoleh 18 unit percobaan. Apabila hasil analisis ragam berpengaruh nyata, maka dilakukan uji lanjut dengan uji BNJ pada taraf nyata $5 \%$.

\section{Parameter Penelitian}

Parameter yang diamati dalam penelitian ini meliputi uji kimia dan organoleptik. Uji kimia yang dilakukan yaitu penentuan kadar air, kadar pati dan kadar abu menggunakan pengujian berdasarkan Sudarmadji, dkk. 1997. Sedangkan uji organoleptik meliputi warna, rasa, dan tekstur menggunakan pengujian berdasarkan Kartika, dkk, 1988.

\section{Tempat Penelitian}

Penelitian ini dilaksanakan di laboratorium Pengolahan hasil pertanian dan laboratorium kimia fakultas pertanian universitas muhammadiyah mataram.

\section{Tahapan Penelitian}

Tahapan penelitian diawali dengan penyiapan bahan baku dan bahan pendukung lainnya untuk 
pembuatan cake. Tahapan penelitian dapat dilihat pada gambar 1 .

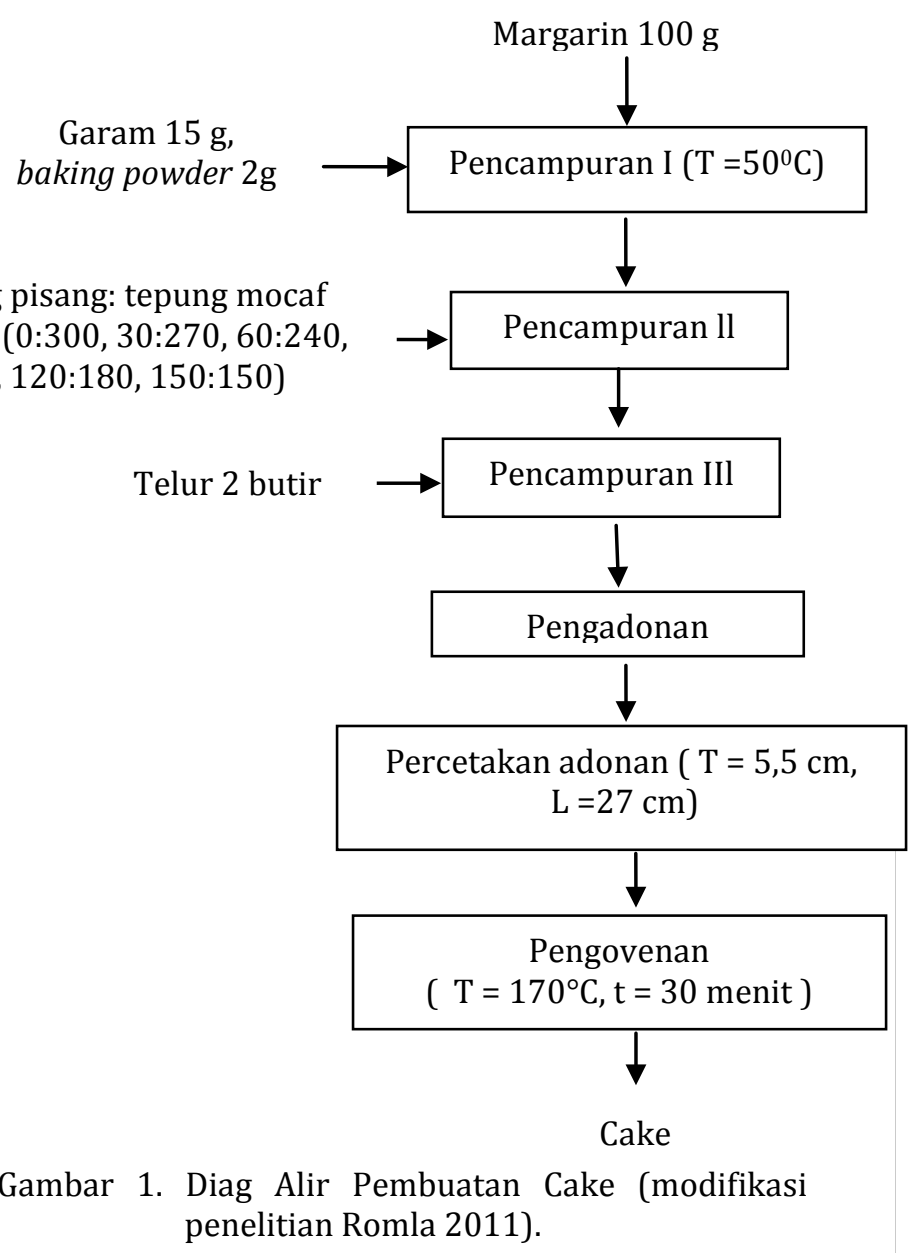

\section{ASIL DAN PEMBAHASAN}

\section{Hasil Penelitian}

Data penelitian dan analisis keragaman hasil dan uji lanjutnya terhadap parameter yang diamati pada cake dapat dilihat pada tabel 2 dan tabel 3.

Tabel 2. Purata Hasil Analisis Sifat Kimia Cake Pada Berbagai Formulasi Tepung Pisang dan Tepung Mocaf

\begin{tabular}{clll}
\hline Perlakuan & Kadar Air & Kadar Abu & Kadar Pati \\
\hline P0 & $5,38 \mathrm{a}$ & $1,44 \mathrm{a}$ & $3,75 \mathrm{a}$ \\
P1 & $7,44 \mathrm{~b}$ & $2,89 \mathrm{~b}$ & $5,14 \mathrm{~b}$ \\
P2 & $8,37 \mathrm{c}$ & $4,66 \mathrm{c}$ & $6,97 \mathrm{c}$ \\
P3 & $9,26 \mathrm{~d}$ & $5,86 \mathrm{~d}$ & $8,41 \mathrm{~d}$ \\
P4 & $10,18 \mathrm{e}$ & $6,79 \mathrm{e}$ & $8,73 \mathrm{de}$ \\
P5 & $11,23 \mathrm{f}$ & $7,95 \mathrm{f}$ & $9,52 \mathrm{e}$ \\
\hline BNJ 5\% & 0,389 & 0,491 & 0,885 \\
\hline
\end{tabular}

Keterangan : Angka yang diikuti oleh huruf yang sama pada kolom yang sama tidak berbeda nyata pada taraf $5 \%$

Tabel 3. Purata Hasil Analisis Sifat Organoleptik (Skor Nilai Rasa, Warna, dan Tekstur) Cake pada Berbagai Perlakuan Formulasi Tepung Pisang dan Tepung Mocaf.

\begin{tabular}{clll}
\hline Perlakuan & \multicolumn{1}{c}{ Rasa } & Warna & Tekstur \\
\hline P0 & $3,050 \mathrm{a}$ & $4,750 \mathrm{~d}$ & $4,440 \mathrm{~d}$ \\
P1 & $3,400 \mathrm{ab}$ & $4,400 \mathrm{~cd}$ & $4,000 \mathrm{c}$ \\
P2 & $3,650 \mathrm{~b}$ & $3,900 \mathrm{bc}$ & $3,550 \mathrm{~b}$
\end{tabular}

\begin{tabular}{clll} 
P3 & $3,700 \mathrm{~b}$ & $3,650 \mathrm{~b}$ & $3,350 \mathrm{ab}$ \\
P4 & $4,300 \mathrm{c}$ & $3,350 \mathrm{ab}$ & $3,200 \mathrm{ab}$ \\
P5 & $4,650 \mathrm{c}$ & $2,850 \mathrm{a}$ & $3,050 \mathrm{a}$ \\
\hline BNJ 5\% & 0,470 & 0.670 & 0,351 \\
\hline
\end{tabular}

Keterangan: Angka-angka yang diikuti oleh huruf yang sama pada kolom yang sama tidak berbeda nyata pada taraf $5 \%$

\section{Pembahasan}

\section{a. Kadar Air}

Hasil penelitian kadar air menunjukkan bahwa semakin tinggi proporsi tepung pisang, maka kadar air yang diperoleh pada cake semakin meningkat. Kadar air tertinggi diperoleh pada perlakuan P5 (Tepung pisang 50\% dan tepung mocaf 50\%), yaitu sebesar $11.233 \%$ dan kadar terendah terdapat perlakuan P0 (Tepung mocaf 100\%) yaitu sebesar 5.377\%. Hubungan pengaruh proporsi tepung pisang dan tepung mocaf terhadap kadar air cake dapat dilihat pada Gambar 1.

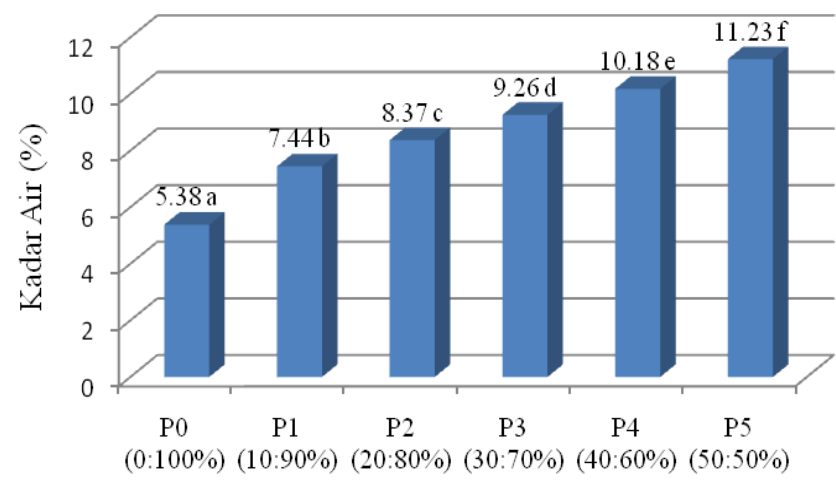

Tepung Pisang dan Tepung Mocaf

Gambar 1. Grafik Hubungan Formulasi Tepung Pisang dan Tepung Mocaf Terhadap Kadar Air Cake

Hasil penelitian kadar air cake menunjukkan adanya pengaruh perbedaan yang nyata dimana semakin tinggi proporsi tepung pisang menyebabkan kadar air cake semakin tinggi, hal ini disebabkan karena tingginya kandungan air yang berasal dari tepung pisang. Suyatni dan Supriadi A., (2008), mengungkapkan bahwa kandungan kadar air pada tepung pisang yaitu 9,08\%. Sehingga semakin banyak proporsi tepung pisang akan menyebabkan kadar air semakin tinggi. Selain itu, kadar air bahan baku tepung mocaf memiliki kadar air lebih rendah yaitu sebesar 6,9\%. Hal ini karena tepung mocaf berfungsi untuk mengikat dan membantu menghasilkan adonan yang homogen karena tepung mocaf lebih fleksibel mudah tercampur dan lebih efesien. 


\section{b. Kadar Abu}

Hasil penelitian Kadar Abu menunjukkan bahwa semakin tinggi proporsi tepung pisang, maka kadar kadar abu yang diperoleh pada cake semakin meningkat kadar kadar abu tertinggi diperoleh pada perlakuan P5 (Tepung pisang 50\% dan tepung mocaf 50\%), yaitu sebesar $7.950 \%$ dan kadar terendah terdapat perlakuan P0 (Tepung mocaf 100\%) yaitu sebesar 1.443\%. Hubungan formulasi tepung pisang dan tepung mocaf terhadap kadar abu cake dapat dilihat pada Gambar 2.

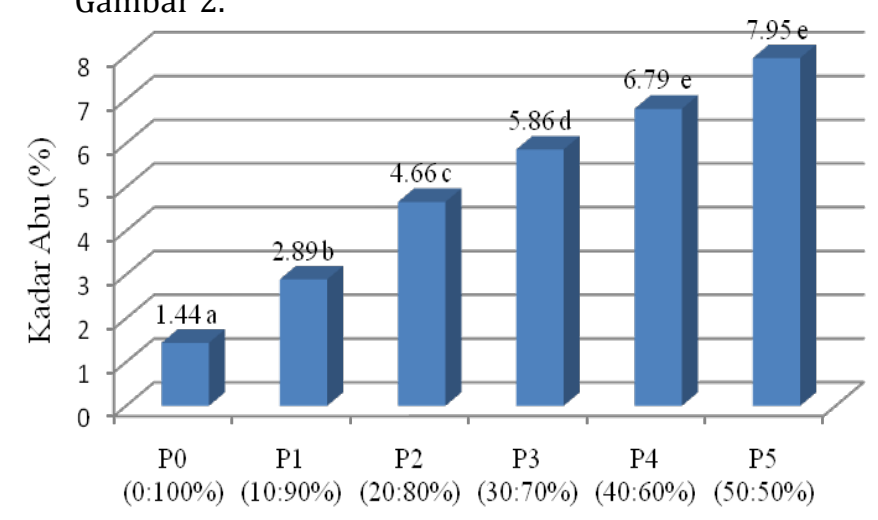

Tepung Pisang dan Tepung Mocaf

Gambar 2. Grafik Hubungan Formulasi Tepung Pisang dan Tepung Mocaf Terhadap Kadar Abu Cake

Hasil pengamatan kadar abu cake menunjukkan bahwa semakin tinggi proporsi tepung pisang menyebabkan kadar abu cake semakin tinggi. Hal ini disebabkan karena tingginya kandungan abu yang berasal dari tepung pisang yaitu. Suyatni dan Supriadi A., (2008), mengungkapkan bahwa kandungan kadar abu pada tepung pisang yaitu $2.98 \%$. Selain itu, kandungan abu juga berasal dari tepung mocaf.

\section{c. Kadar Pati}

Hasil penelitian Kadar Pati menunjukkan bahwa semakin tinggi formulasi tepung pisang, maka kadar pati yang diperoleh pada cake semakin tinggi. Kadar pati tertinggi diperoleh pada perlakuan P5 (Tepung pisang 50\% dan tepung mocaf $50 \%$ ), yaitu sebesar $9.52 \%$ dan kadar pati terendah terdapat perlakuan P0 (Tepung mocaf 100\%) yaitu sebesar 3.75\%. Hubungan pengaruh formulasi tepung pisang dan tepung mocaf terhadap kadar pati cake dapat dilihat pada Gambar 3.

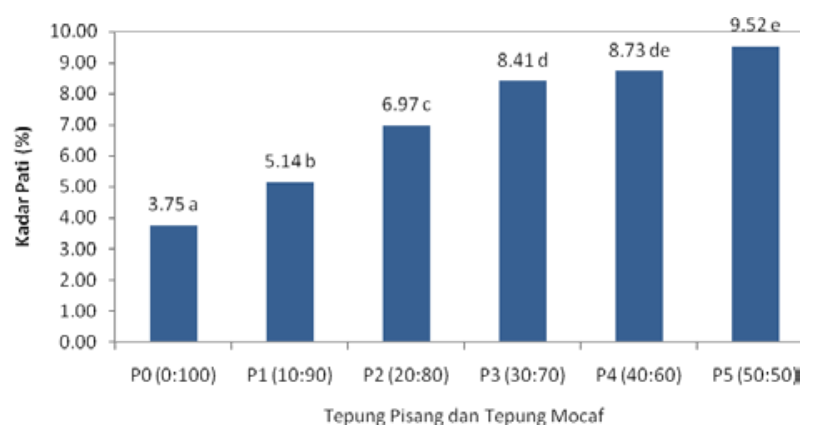

Gambar 3. Grafik Hubungan Formulasi Tepung Pisang dan Tepung Mocaf Terhadap Kadar pati Cake

Hasil pengamatan kadar pati cake menunjukkan adanya pengaruh nyata dimana semakin tinggi formulasi tepung pisang maka semakin tinggi kadar pati dari cake yang dihasilkan. Peningkatan kadar pati pada cake disebabkan karena tingginya kadar pati tepung pisang, sehingga semakin banyak penambahan tepung pisang yang ditambahkan maka kadar pati cake semakin meningkat. Sementara Suyatni dan Supriadi A., (2008), menyatakan bahwa kadar pati dalam tepung pisang sebesar $82,81 \%$. Selain itu, tepung pisang kaya akan kadar pati sehingga semakin banyak penambahan tepung pisang maka semakin tinggi kadar pati yang ada pada cake. Hal tersebut diperkuat oleh pendapat Winarno (2004), yang menyatakan bahwa dalam tepung pisang terkandung beberapa unsur makro dan mikronutrien, diperkirakan, sehingga kandungan kadar pati semakin tinggi.

\section{d. Nilai Rasa}

Hasil penelitian menunjukkan bahwa semakin tinggi proporsi tepung pisang, maka skor kesukaan terhadap nilai rasa yang diperoleh pada cake semakin tinggi. Skor nilai rasa tertinggi diperoleh pada perlakuan P5 (Tepung pisang 50\% dan tepung mocaf $50 \%$ ), yaitu sebesar 4.650 dengan kriteria mendekati ungu kemerahan dan terendah terdapat perlakuan P0 (Tepung mocaf $100 \%$ ) yaitu sebesar 3.050 dengan kriteria ungu. Hubungan pengaruh proporsi tepung pisang dan tepung mocaf terhadap skor nilai rasa cake dapat dilihat pada Gambar 4 . 


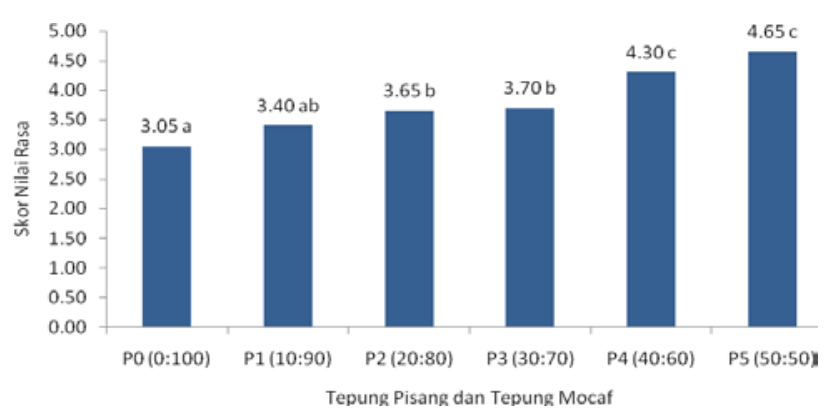

Gambar 4. Grafik Hubungan Formulasi Tepung Pisang dan Tepung Mocaf Terhadap Nilai Rasa Cake

Hasil Penelitian skor nilai rasa cake terlihat bahwa skor nilai kesukaan terhadap rasa semakin meningkat dengan semakin tingginya proporsi tepung pisang. Hal ini disebabkan karena proporsi tepung pisang yang lebih banyak menimbulkan rasa yang disukai panelis, karena tepung pisang yang digunakan memiliki rasa khas pisang yang semakin terasa manis sehingga disukai panelis. Hal tersebut diperkuat oleh pendapat Winarno (2004), menerangkan bahwa tingkat rasa yang tinggi dari produk cake yang dihasilkan dipengaruhi oleh penambahan tepung pisang, selain itu proses pengolahanpun tidak kalah penting, seperti proses pencampuran (mixing) dari bumbu yang ditambahkan.

\section{e. Nilai Warna}

Hasil penelitian Nilai Warna menunjukkan bahwa semakin tinggi formulasi tepung pisang, maka skor kesukaan terhadap nilai warna yang diperoleh pada cake semakin rendah. Skor nilai warna tertinggi diperoleh pada perlakuan P0 (Tepung mocaf 100\%), yaitu sebesar 4.750 dengan kriteria krem dan terendah terdapat perlakuan P5 (Tepung pisang 50\% dan tepung mocaf 50\%) yaitu sebesar 2.850 dengan kriteria cokelat. Hubungan pengaruh proporsi tepung pisang dan tepung mocaf terhadap skor nilai rasa cake dapat dilihat pada Gambar 5.

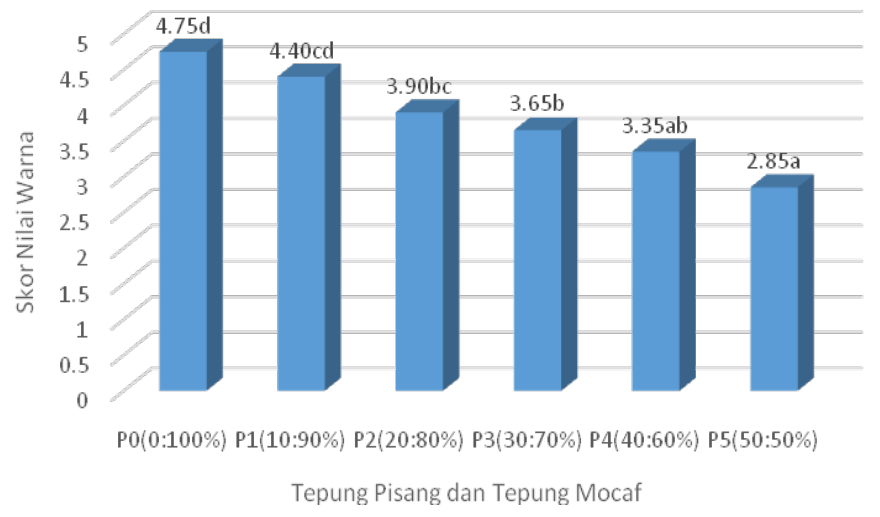

Gambar 5. Grafik Hubungan Formulasi Tepung Pisang dan Tepung Mocaf Terhadap Skor Nilai Warna Cake
Pada hasil penelitian menunjukkan bahwa skor nilai kesukaan terhadap warna semakin menurun dengan semakin tingginya formulasi tepung mocaf. Hal ini disebabkan karena proporsi tepung mocaf yang lebih banyak menimbulkan warna yang disukai panelis, karena tepung mocaf yang digunakan memiliki warna putih sedangkan rendahnya skor nilai warna dengan kriteria cokelat disebabkan proporsi tepung mocaf yang lebih sedikit sehingga warna cake kurang disukai oleh panelis. Warna sangat berpengaruh terhadap kualitas bahan pangan dalam hal ini cake, karena merupakan salah satu penilaian terhadap mutu bahan pangan tersebut. Hal ini sesuai dengan pendapat winarno (2004), bahwa penentuan mutu suatu bahan pangan pada umumnya tergantung pada warna, karena warna tampil terlebih dahulu dan kadang-kadang menentukan mutu dari bahan pangan.

\section{f. Nilai Tekstur}

Hasil penelitian skor Nilai Tekstur menunjukkan bahwa semakin tinggi formulasi tepung pisang, maka skor nilai tekstur yang diperoleh pada cake semakin rendah. Nilai tekstur tertinggi diperoleh pada perlakuan P0 (Tepung mocaf $100 \%$ ), yaitu sebesar 4.40 dengan kriteria sangat empuk dan nilai tekstur terendah terdapat perlakuan P5 (Tepung pisang 50\% dan tepung mocaf 50\%) yaitu sebesar 3.05 dengan kriteria keras. Hubungan pengaruh proporsi tepung pisang dan tepung mocaf terhadap skor nilai tekstur cake dapat dilihat pada Gambar 6 .

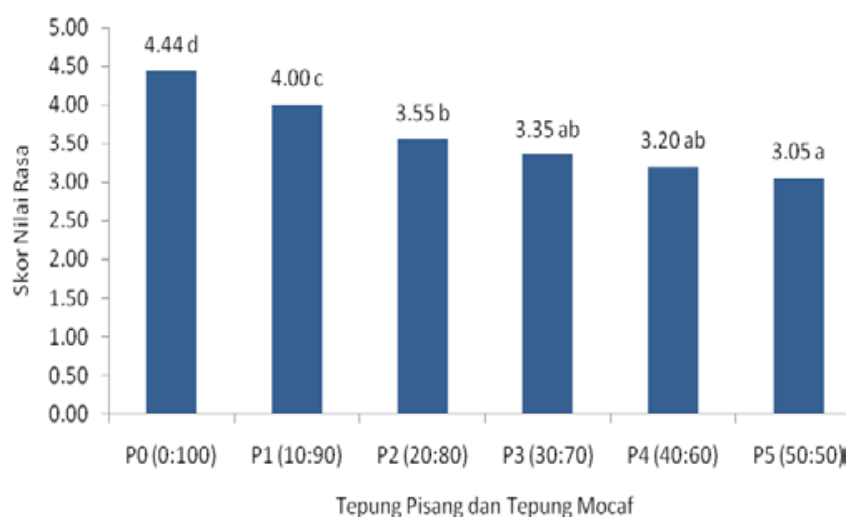

Gambar 6. Grafik Hubungan Formulasi Tepung Pisang dan Tepung Mocaf Terhadap Skor Nilai Tekstur Cake

Hasil penelitian skor nilai tekstur terlihat bahwa skor nilai tekstur semakin menurun dengan semakin tingginya formulasi tepung pisang. Hal ini dipengaruhi adanya proporsi tepung pisang yang tinggi, yang mengakibatkan tingginya kadar air cake. Hal ini sesuai dengan 
pendapat Anonim (2007), bahwa pada pembuatan cake, komposisi adonan akan sangat menentukan kualitas cake nantinya. Salah satu faktor yang menentukan kualitas cake adalah kekentalan pada adonan cake yang akan berpengaruh pada tingkat kehalusan tekstur, serta ketahanan cake.

\section{SIMPULAN DAN SARAN}

\section{SIMPULAN}

1. Formulasi Tepung Pisang dan Tepung Mocaf berpengaruh secara nyata terhadap semua parameter sifat kimia yaitu kadar air, kadar abu, dan kadar pati, dan sifat organoleptik parameter rasa, warna, dan tekstur cake yang diamati.

2. Semakin tinggi formulasi tepung pisang yang digunakan maka kadar air, abu, dan pati semakin tinggi dan skor nilai rasa semakin meningkat dan disukai oleh panelis, sedangkan nilai warna dan nilai tekstur cendrung semakin menurun.

3. Perlakuan terbaik diperoleh P5 (Tepung pisang $50 \%$ dan tepung mocaf 50\%) dengan kadar air $11,23 \%$. Kadar abu 7,95\% Kadar pati 9,52\% dan skor nilai rasa 4,650 agak suka, warna 4,750 putih tekstur 4,440 sangat empuk.

\section{SARAN}

1. Dalam pembuatan cake dengan formulasi Tepung pisang 50\% dan tepung mocaf $50 \%$ (perlakuan P5) masih disukai oleh panelis dengan menampilkan rasa yang disukai dan warna krem kekuningan

2. Perlu dilakukan penelitian lanjutan mengenai variasi formulasi tepung yang berbeda dalam pembuatan cake

\section{UCAPAN TERIMA KASIH}

Penulis mengucapkan terima kasih kepada Universitas Muhammadiyah Mataram atas dukungan materil dalam melaksanakan penelitian ini sehingga berjalan dengan lancar dan mendapatkan hasil yang baik.

\section{DAFTAR RUJ UKAN}

[1] Departemen Kesehatan RI, 1997. Daftar Komposisi Bahan Makanan. Bhratara Karya Aksara, Jakarta.

[2] Faridah, Ani, Kasmita S., Asmar Yusuf, 2008. Patiseri Jilid 2 Untuk SMK. Direktorat Pembinaan Sekolah Menengah. Departemen Pendidikan Nasional. Jakarta.

[3] Hanafiah K. A., 1994. Rancangan Percobaan, Teori dan Aplikasi. Raja Grafindo Persada, Jakarta.
[4] Kartika, B., Hastuti,P dan Supartono, w. 1988. Pedoman Uji Indrawi Bahan Pangan. PAU

[5] Mocaf Indonesia, 2016. Peluang Pengembangan Tepung Mocaf. Available online with update at http://mocafindonesia.com. (verified at $20^{\text {th }}$ Oktober 2016.

[6] Nurhayati, C dan Andayani ., 2014. Jurnal Dinamika Penelitian Tepung Pisang Industri Vol. 25 No.1. Balai Riset dan Standarisasi. Palembang.

[7] Raysita, N dan Pangesthi, L.T, 2012. Jurnal Pengaruh Proporsi Tepung Terigu dan Tepung Mocaf (Modified Cassava Flour Terhadap Tingkat Kesukaan Cake. Program Studi S1 Pendidikan Tata Boga Fakultas Teknik Universitas Negeri Surabaya. Surabaya.

[8] Romla, N, 2013. Skripsi Penegndalian Mutu Cake Mocaf Ubi Jalar Unggu. Program Studi Teknologi Hasil Pertanian Fakultas Pertanian Universitas Sebelas Maret. Surabaya.

[9] Setiavani, G. 2013. Teknologi Pembuatan Makanan Dengan Menggunakan Tepung Mocaf Sebagai Subsitusi Tepung Terigu. http://www.stppmedan.ac.id.. Diakses tanggal 20 maret 2015.

[10]Sutardi, 2010. Bisnis Ubi Kayu Indonesia. Fakultas Teknologi Pertanian Universitas Gajah Mada. Yogyakarta

[11] Sudarmadji, S., Haryono B. dan Suhardi (1997). Prosedur Analisa untuk Bahan Makanan dan Pertanian. Liberty, Yogyakarta.

[12] Suyatni dan Supriadi A., 2008. Pisang, Budidaya, Pengolahan dan Prospek Pasar. Cet.19 (edisi Revisi Penebar Swadaya. Jakarta

[13]Winarno, F.G., 2004. Kimia Pangan dan Gizi Gramedia Pustaka Utama. Jakarta. 